\title{
ESTETIKA VISUAL KORIDOR PADA BANGUNAN-BANGUNAN KOMERSIL DI JALAN PANDANARAN SEMARANG
}

\author{
Mutiawati Mandaka \\ Universitas Pandanaran \\ Jl. Banjarsari Barat No. 1, Pedalangan, Banyumanik, Semarang \\ email: mutia.mandaka@yahoo.com
}

\begin{abstract}
Semarang, as a big city, has rapidly developed in buildings. It is indicated mainly by the increasing number of commercial buildings such as supermarkets, office buildings and mall. It also occurred on Pandanaran street, where buildings use for housings become commercial buildings. Signage is needed to give the identity of building which is used as communication tool in architecture and direct information for community. Based on function, there are four reason why signage is needed in a city: traffic sign, commercial identity, informational sign and mall identity. In fact, on Pandanaran street, signage is dominated by commercial identity. Besides the trespassing line, the commercial corridor has developing to be the media for expressing and giving information, because advertising is the effective way to win the market competition. This research is aimed to find the influence of signage to visual aesthetic corridor on Pandanaran street in Semarang. Based on literature and existing condition, the elements that construct the character of visual corridor are façade the typhology of space and its activity.
\end{abstract}

Keyword: urban design, signage, visual corridor, aesthetic

\section{PENDAHULUAN}

Pesatnya pertumbuhan ekonomi memunculkan masalah baru di dalam kota, urban space digunakan untuk menyampaikan pesan-pesan atau informasi yang benar-benar berfungsi atau suatu simbol untuk meyakinkan masyarakat. Hal ini tidak dapat dihindari, karena masyarakat membutuhkan informasi murah dan cepat. Selanjutnya fungsi signage sebagai sarana komunikasi berkembang menjadi sarana informasi untuk memenangkan persaingan pasar. Sehingga ruang kota seperti koridor komersial didominasi oleh signage (terutama papan-papan reklame).

Ada dua kategori signs (Carr, 1973) :

1. Public environmental information, semua jenis informasi berhubungan dengan kondisi dari area kawasan. Dan peraturanperaturan yang dibutuhkan pada area kawasan tersebut seperti traffic signs, nama jalan, papan informasi, area informasi, rute bis.

2. Private signs, adalah penanda yang berhubungan dengan aktivitas komersial dan bisnis.

Private sign atau commercial signs mempunyai beberapa bentuk seperti signboard, spanduk, marquee (tempat berteduh seperti atap di muka pintu masuk sebuah gedung), kanopi, awning (tenda rumah), window display dan semua media visual ruang luar. Signboard adalah bentuk yang paling banyak digunakan dalam commercial signs. Plang dokter, penanda toko, produk-produk advertisement dan papan pengumuman adalah contoh-contoh dari signboard. Signboard biasanya berbentuk tiga dimensi dan diletakkan dengan konstruksi khusus (Mandelker dan Ewald, 1988).

Pada era informasi dan era perkembangan yang sangat pesat di berbagai negara membuat gaya hidup masyarakat menjadi berubah. Yang telah banyak dipengaruhi oleh cara produk advertisement dan pelayanan kepada konsumen atau masyarakat umum. Papan reklame merupakan elemen visual yang semakin penting artinya dalam perancangan kota. Tanda-tanda petunjuk jalan, arah ke suatu kawasan tertentu pada jalan tol atau di jalan kawasan pusat kota semakin membuat semarak atmosfer lingkungan kota tersebut. Peraturan yang mengatur tentang tanda-tanda tersebut untuk sebagian kota di Indonesia masih belum sepenuhnya diatur hingga pada masalah teknis. Akibatnya perkembangan papan-papan reklame terutama, mengalami persaingan yang berlebihan baik dalam penempatan titik- 
titiknya, dimensi atau ukuran billboardnya, kecocokan bentuk, dan pengaruh visual terhadap lingkungan kota. Hal ini terjadi karena ketidakpastian pengelola kota akan perangkat hukum baik mengatur masalah teknis maupun non teknis. Dan masalah ini terjadi pada beberapa area kawasan yang memiliki keterbatasan perencanaan dan desain guidelines.

Penempatan papan reklame pada bangunan berhubungan dengan kondisi dari area kawasan, jadi penempatannya dapat menjadi dampak positif atau negatif pada area kawasan tersebut (Chermayeff, 1981). Bangunanbangunan adalah elemen-elemen urban design dan signage atau papan reklame yang menempel pada bangunan-bangunan mempunyai pengaruh yang besar pada kualitas visual area urban (Carr,1973). Adapun beberapa point penting yang dijadikan alasan mengapa harus ada kajian khusus mengenai pengaruh signage pada koridor komersil kaitannya dengan estetika visual koridor dalam penelitian ini adalah :

1. Perubahan peruntukan lahan di sepanjang jalan Pandanaran menjadi kawasan perdagangan yang pesat dan didukung dengan link antara Simpang Lima sebagai CBD dengan Monumen Tugu Muda menyebabkan munculnya bangunanbangunan besar (komersil) yang diikuti pemasangan papan reklame/signage disepanjang koridor jalan Pandanaran.

2. Kehadiran papan-papan reklame/signage tersebut di koridor jalan Pandanaran cenderung lebih memanfaatkan potensi ekonomi kawasan secara maksimal. Terjadi pergeseran fungsi ruang kota menjadi ruang ekspresi media iklan untuk memenangkan persaingan pasar sehingga mempengaruhi keberadaan signage yang berada pada koridor.

3. Koridor jalan Pandanaran Semarang yang merupakan koridor penghubung antara Simpang Lima dan Tugu Muda didominasi oleh papan advertensi

Sebagai salah satu elemen urban design, signage (commercial identity) memiliki peranan tersendiri dalam membentuk karakter kawasan. Dan koridor komersial ini merupakan jalur penghubung menuju kawasan Simpang Lima/Tugu Muda dengan moda transport yang sangat padat. Moda transport yang digunakan sangat bercampur dengan aktivitas komersial yang berada di luar bangunan hampir di sepanjang koridor. Berdasarkan hal tersebut diatas maka peneliti mengkaji mengenai pengaruh signage yang terdapat pada bangunan-bangunan komersil terhadap keindahan atau estetika visual koridor jalan Pandanaran Semarang dengan memfokuskan suatu tujuan penelitian sebagai berikut :

1. Identifikasi signage, aktivitas dan visual koridor;

2. Identifikasi faktor-faktor pembentuk visual koridor;

3. Menganalisis keberadaan signage pada angunan-bangunan komersil terhadap estetika visual;

4. Menganalisis faktor-faktor estetika.

\section{MATERI \& METODE}

Urban Design adalah bagian dari proses perencanaan yang berhubungan dengan kualitas lingkungan fisik kota sebagai kelanjutan urban planning (Shirvani, 1985). Amos Rapoport dalam Catanese (1986) menjelaskan bahwa kota tidak akan muncul secara tiba-tiba, hingga tidak mungkin terjadi revolusi kota (urban revolution), karena kota tumbuh secara bertahap sesuai budaya masyarakatnya. Dalam perkembangan suatu kota dibutuhkan suatu penanda bagi suatu kawasan untuk menjadi identitas kota.

Menurut Echols (1975), sign adalah tanda, sedangkan dalam arsitektur sign diartikan sebagai bentuk untuk diartikan sebagai bentukbentuk informasi dan orientasi kota yang dirancang khusus sebagai bagian dari delapan elemen urban design (Shirvani, 1985). Sedangkan Rubenstein (1992) mendefinisikan bahwa signage merupakan tanda-tanda visual di perkotaan yang berfungsi sebagai sarana informasi atau komunikasi secara arsitektural. Senada dengan hal tersebut, Lynch (1962) menyebutkan bahwa sign dapat berfungsi sebagai alat untuk orientasi bagi warga kota. Sama halnya dengan Sanoff (1991) yang mengatakan bahwa signage seperti dalam penggunaan sign, keberadaannya memberikan informasi kepada masyarakat yang sedang melintas, berjalan atau berkendaraan.

Elemen-elemen untuk menganalisa kualitas estetis urban design menurut Moughtin (1992) dan Moughtin et al (1995) terdiri dari keterpaduan, keseimbangan, proporsi, skala, kontras dan harmoni serta ritme. Estetika suatu 
kota dapat tercipta jika elemen-elemen kotanya memiliki unsur-unsur tersebut (Ishar, 1992).

Untuk mengetahui pengaruh signage terhadap estetika visual pada bangunan-bangunan komersil di koridor Jalan Pandanaran dibutuhkan suatu kajian secara menyeluruh dengan penjabaran data dan analisa dengan menggunakan analisis kualitatif dengan metode deskriptif.

Tahapan analisis pada penelitian ini diawali dengan mengumpulkan data penilaian reponden yang dibagi menjadi 3 kelompok yaitu kelompok A (arsitek), kelompok B (masyarakat umum) dan kelompok C ( penghuni).

\begin{tabular}{|c|l|c|}
\hline Strata & \multicolumn{1}{|c|}{ Spesifikasi } & $\begin{array}{c}\text { Jumlah } \\
\text { Responden }\end{array}$ \\
\hline A & $\begin{array}{l}\text { Responden dengan latar belakang pendidikan } \\
\text { arsitektur }\end{array}$ & 30 \\
\hline B & Masyarakat umum & 30 \\
\hline C & $\begin{array}{l}\text { Penghuni, yaitu responden yang tiap hari berada di } \\
\text { jalan Pandanaran }\end{array}$ & 30 \\
\hline
\end{tabular}

Tabel 1. Penentuan Jumlah Responden (sumber : data primer yang diolah, 2004)

Sedangkan untuk menilai estetika visual koridor jalan Pandanaran Semarang ini diperlukan indikator-indikator seperti keterpaduan (unity), proporsi (proportion), skala (scale), keseimbangan (balance), ritme (rhythm), warna (colour) dan pandangan berseri (serial vision). Kemudian untuk mengetahui tanggapan masyarakat terhadap variabel signage secara kualitatif dibagi dengan jawaban sangat setuju, setuju, raguragu, tidak setuju dan sangat tidak setuju (sesuai skor nilai yang sudah ditentukan) seperti tertera pada tabel berikut:

\begin{tabular}{|c|c|c|c|c|c|c|c|}
\hline \multicolumn{2}{|c|}{ Keterangan } & \multicolumn{2}{|c|}{ Arsitek } & \multicolumn{2}{|c|}{ Umum } & \multicolumn{2}{|c|}{ Penghuni } \\
\hline Penilaian & Skor & $\mathrm{Jmlh}$ & Prosentase & Jmlh & Prosentase & $\mathrm{Jmlh}$ & Prosentase \\
\hline SS & 50 & 1 & 3,33 & 0 & 0,00 & 0 & 0,00 \\
\hline $\mathrm{s}$ & 40 & 12 & 40,00 & 13 & 43,33 & 11 & 36,67 \\
\hline $\mathrm{R}$ & 30 & 16 & 33 & 16 & 3,33 & 18 & 60,00 \\
\hline TS & 20 & 1 & 3,33 & 1 & 3,33 & 1 & 3,33 \\
\hline STS & 10 & 0 & 0,00 & 0 & 0,00 & 0 & 0,00 \\
\hline jumla & & 30 & 100.00 & 30 & 100,00 & 30 & 100,00 \\
\hline
\end{tabular}

Tabel 2. Tanggapan Responden Terhadap Signage

Dan untuk mengetahui validitas data dilakukan dengan uji validitas dengan indikator "r" (Product Moment Pearson), menggunakan SPSS dengan teknik korelasi. Kemudian untuk mengetahui ada pengaruh signage atau tidaknya dilakukan dengan teknik regresi. Hasil dari analisis tersebut berupa data yang diperoleh cukup banyak sehingga selanjutnya data direduksi dan dikelompokkan dengan membuat tabel-tabel sesuai dengan strata yang telah ditentukan. Dari proses ini diperoleh penilaian dari masing-masing kelompok responden yang selanjutnya akan menghasilkan suatu kesimpulan dan rekomendasi apakah keberadaan signage pada bangunan-bangunan komersil di koridor Jalan Pandanaran sudah memenuhi kualitas estetika yang baik atau belum.

\section{HASIL DAN PEMBAHASAN}

\section{Area Studi}

Jalan Pandanaran adalah satu koridor komersial di kota Semarang. Pada tahun 1970, kawasan Pandanaran merupakan lingkungan hunian. Dengan adanya perubahan peruntukan kawasan dari permukiman menjadi kawasan perdagangan, maka terjadi perubahan pada kondisi jalan Pandanaran yang semula memiliki lebar 6 meter tanpa jalur pedestrian mengalami perubahan menjadi lebar 30 meter dengan pohon-pohon di kanan dan kiri jalan dan dilengkapi oleh jalur pedestrian.

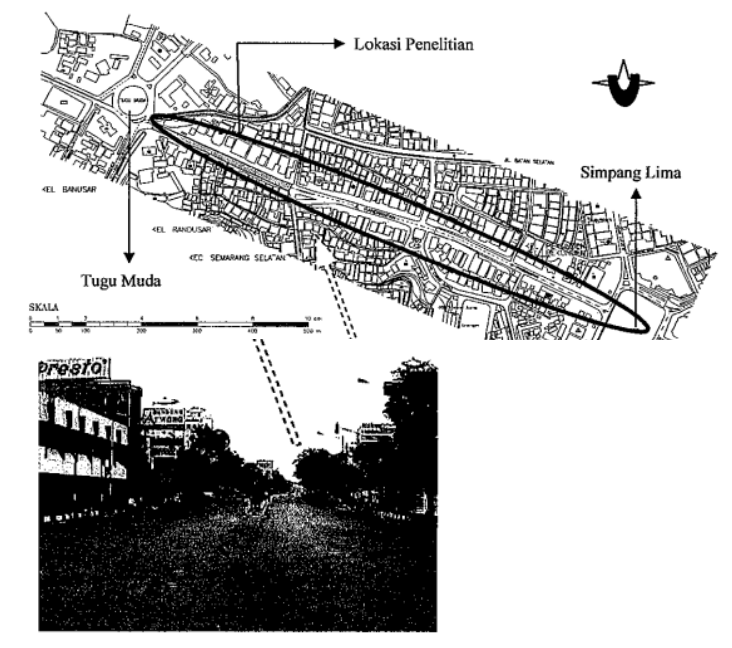

Gambar 1. Peta Lokasi Penelitian Koridor Jalan Pandanaran pagi hari tampak lengang (Sumber : Foto Udara Dinas Pekerjaan Umum, Survei dan analisa)

Lokasi jalan Pandanaran ini sangat strategis bagi kawasan perdagangan, dimana koridor jalan Pandanaran ini menghubungkan antara kawasan Central Business District Simpang Lima dengan landmark kota Semarang (Tugu Muda). Sebagai koridor komersial keberadaan signage sangat dominan, kondisi tersebut 
memang tidak bisa dihindari dan akan selalu meningkat dan keberadaan signage dapat menjadikan penanda bagi suatu kehidupan kota.

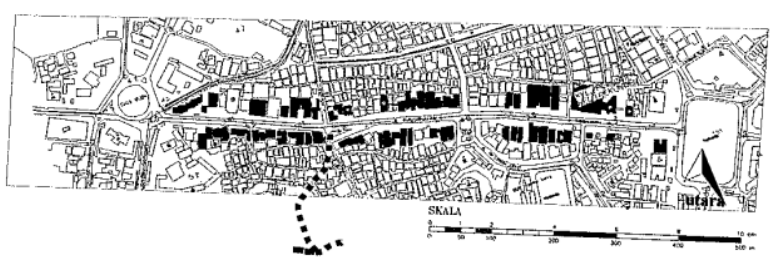

Gambar 2. Peta bangunan-bangunan komersial

(lokasi penempatan signage) di koridor jalan

Pandanaran (Sumber : survei lapangan)

\section{Analisa dan Pembahasan}

Dari analisa yang dilakukan dilapangan maka ditemukan pengaruh signage pada bangunan-bangunan komersil terhadap estetika visual koridor jalan Pandanaran Semarang antara lain :

1. Berdasarkan hasil uji validitas variabel signage terhadap estetika visual menyatakan bahwa variabel-variabel tersebut valid (dengan derajat kebebasan $(\mathrm{df})=\mathrm{n}-2$ dan tingkat signifikan $=95 \%$ atau $\alpha=0,05$; untuk $\mathrm{n}=30$ diperoleh nilai $\mathrm{r}$ tabel sebesar 0,371). Hasil uji validitas ternyata lebih besar dari 0,371 dan variabelvariabel signage maupun estetika visual dinyatakan valid sehingga dapat digunakan untuk mencari pengaruh signage terhadap estetika visual.

2. Dengan menggunakan uji regresi untuk mencari pengaruh variabel signage terhadap estetika visual maka hasilnya dapat dilihat pada tabel berikut :

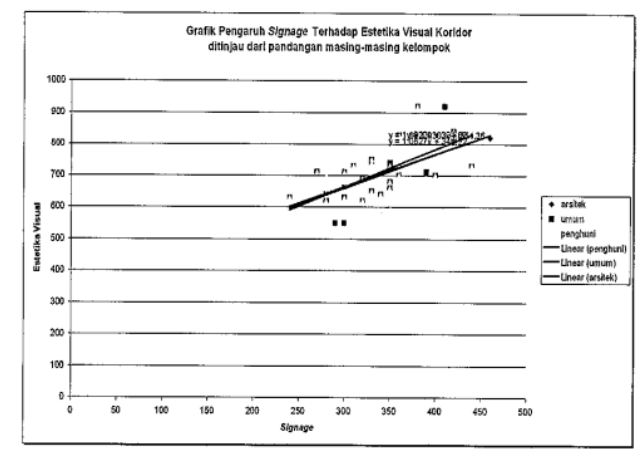

Diagram 1. Grafik Pengaruh Signage Terhadap

Estetika Visual Koridor Ditinjau dari

Pandangan Responden Arsitek, Masyarakat Umum dan Penghuni.

Dari hasil uji regresi pada masing-masing kelompok responden ternyata menghasilkan nilai positif yang berarti terdapat pengaruh signage terhadap estetika visual koridor, dengan penilaian sebagai berikut :

a. Untuk responden Arsitek menilai signage rata-rata (dengan jumlah data 30) adalah 302,67 dengan standart deviasi 45,253. Sedang nilai untuk estetika visual sendiri (dengan jumlah data 30) adalah 639,67 dengan standard deviasi 90,534. Besar hubungan antar variabel cukup erat $(0,613)$ dan arah hubungan positif dengan tingkat kepercayaan mendekati 100\%. Angka r square hanya 0,367 yang berarti $37,6 \%$ estetika visual dapat dijelaskan oleh variabel signage sedang sisanya $62,4 \%$ dijelaskan oleh faktor-faktor lain. Dengan demikian dapat dilihat pada diagram 1 persamaan regresi untuk responden arsitek $\mathrm{y}=268,502+1,226 \mathrm{x}$, dimana $\mathrm{y}=$ estetika visual dan $\mathrm{x}=$ signage.

b. Untuk responden masyarakat umum menilai signage rata-rata (dengan jumlah data 30) adalah 341,67 dengan standard deviasi 52,659. Sedang nilai untuk estetika visual sendiri (dengan jumlah data 30) adalah 698,33 dengan standard deviasi 52,659 . Sedang nilai untuk estetika visual sendiri (dengan jumlah data 30) adalah 698,33 dengan standard deviasi 93,517. Besar hubungan antar variabel cukup erat $(0,654)$ dan arah hubungan positif dengan tingkat kepercayaan mendekati $100 \%$. Angka $\mathrm{r}$ square hanya 0,428 yang berarti $42,8 \%$ estetika visual dapat dijelaskan oleh variabel signage sedang sisanya $57,2 \%$ dijelaskan oleh faktor-faktor lain. Dengan demikian dapat dilihat pada diagram 1 persamaan regresi untuk responden masyarakat umum $\mathrm{y}=301,575+1,161 \mathrm{x}$, dimana $\mathrm{y}=$ estetika visual dan $\mathrm{x}=$ signage.

c. Untuk responden penghuni menilai signage rata-rata (dengan jumlah data 30) adalah 331,67 dengan standard deviasi 48,642. Sedang nilai untuk estetika visual sendiri (dengan jumlah data 30) adalah 694,33 dengan standard deviasi 83,900. Besar hubungan antar variabel cukup erat $(0,569)$ dan arah hubungan positif dengan tingkat kepercayaan mendekati 99,9\%. Angka r square hanya 0,324 yang berarti $32,4 \%$ estetika visual dapat dijelaskan oleh variabel signage sedang sisanya $67,6 \%$ dijelaskan oleh faktor-faktor lain. Dengan demikian dapat dilihat pada diagram 1 
persamaan regresi untuk responden penghuni $\mathrm{y}=368,628+0,928 \mathrm{x}$, dimana $\mathrm{y}=$ estetika visual dan $\mathrm{x}=$ signage.

Garis pada diagram 1 menunjukkan arah naik yang berarti terdapat pengaruh signage terhadap estetika visual koridor (positif $\rightarrow$ arah garis naik dari bawah ke atas). Dengan catatan jika signage pada bangunan-bangunan komersil yang ada di koridor jalan Pandanaran baik maka dapat meningkatkan kualitas estetika visual koridor tersebut sedangkan jika signage yang ada di koridor jalan Pandanaran buruk maka akan memperburuk kualitas estetika visual koridor.

3. Hasil pengolahan data yang didapat dari kuesioner yang dibagikan kepada para responden menghasilkan bahwa rata-rata dari seluruh responden memandang bahwa signage pada bangunan-bangunan komersil di koridor jalan Pandanaran adalah sedang (tidak terlalu baik ataupun buruk dengan prosentase $53,33 \%$ pandangan arsitek, $53,33 \%$ pandangan umum dan $60 \%$ pandangan penghuni). Dengan penilaian dari faktor-faktor estetika visual seperti keterpaduan, proporsi, keseimbangan, skala, ritme, warna dan serial vision para responden (baik arsitek, masyarakat umum dan penghuni) memandang bahwa :

a. Unity signage di koridor Pandanaran sudah baik (pandangan responden arsittek sebesar $50 \%$ pandangan masyarakat umum $46,67 \%$ dan penghuni sebesar $40 \%$ )

b. Proporsi signage tidak terlalu baik ataupun buruk (sedang). Pandangan responden penghuni sebesar $60 \%$, pandangan arsitek dan masyarakat umum masing-masing sebesar 53,33\%.

c. Skala signage sudah baik, dengan pandangan responden arsitek sebesar $36,67 \%$ yang menyatakan baik dan $10 \%$ sangat baik. Dari responden masyarakat umum $36,67 \%$ responden memandang baik dan $10 \%$ yang sangat baik. Sedangkan responden penghuni memandang baik sebesar $30 \%$ dan $10 \%$ sangat baik.

d. Keseimbangan antar signage ataupun bangunannya juga sudah baik, responden arsitek dan penghuni memandang baik masing-masing $76,67 \%$ dan masyarakat umum memandang baik sebesar $73,33 \%$. e. Ritme (irama dari signage pada bangunan-bangunan komersilnya) baik, jumlah responden arsitek, masyarakat umum dan penghuni yang menyatakan baik masing-masing sebesar $80 \%$ dan sangat baik masing-masingg $10 \%$.

f. Warna dari signage pada bangunanbangunan komersil sudah baik, menurut responden arsitek dan masyarakat umum sebesar $63,33 \%$ warna signage pada bangunan-bangunan komersil di koridor jalan Pandanaran sudah baik. Sedang responden penghuni memandang baik sebesar 53,33\%, sisanya masing-masing $13,33 \%$ responden menyatakan sangat baik.

g. Serial vision menurut para responden sudah cukup bagus, dapat dilihat pada tanggapan responden arsitek dan masyarakat umum sebesar $63,33 \%$ memandang baik dan penghuni memandang $60 \%$ sudah cukup bagus.

4. Berdasarkan analisis grafis serial vision dari arah Barat maupun Timur ternyata terdapat beberapa point penting yaitu pergerakan di koridor sangat terasa dengan perbedaan ketinggian bangunan dan penempatan signage sehingga tidak terkesan terlalu monoton. Pepohonan yang berada di kanan kiri jalan memberikan warna yang berbeda dan juga memberi suatu pemandangan yang menyegarkan mata. Ada kalanya pepohonan ini menghalangi pandangan untuk melihat bangunan yang ada di belakangnya. Publicity terasa pada penggal jalan Kyai Saleh, selain terjadi penumpukan signage di wilayah ini juga terjadi occupied territority yaitu daerah yang dikuasai para pkl penjual jajanan khas kota Semarang. Pada akhir perjalanan serial vision pada koridor ini terdapat vista yaitu Monumen Tugu Muda yang juga berfungsi sebagai eye cathcer koridor.

\section{SIMPULAN}

Berdasarkan analisa yang telah dilakukan maka ada dua hal yang dapat disimpulkan yaitu pertama signage pada bangunanbangunan komersil di koridor jalan Pandanaran memberikan pengaruh positif yang signifikan terhadap estetika visual. Kedua signage tersebut dapat mempengaruhi serial vision di koridor jalan Pandanaran. Adapun hal-hal yang 
menyebabkan pengaruh positif tersebut antara lain :

1. Dominasi fungsi signage di koridor jalan Pandanaran ini lebih dominan sebagai commercial identity sehingga ruang koridor berfungsi sebagai ruang komunikasi yang bersifat komersial.

2. Penyebaran signage tidak merata namun jarak dan lokasinya tidak terlalu dekat ataupun jauh yang menyebabkan penyebaran signage masih cukup teratur.

3. Pada sebagian besar bangunan-bangunan komersil, signage merupakan unsur yang menyatu dengan bangunan tersebut.

4. Faktor-faktor yang menyebabkan kualitas estetika visual koridor jalan Pandanaran meningkat adalah :

a. Kesatuan (unity), terbentuk kesatuan antara unsur-unsur pembentuk koridor.

b. Proporsi (proportion), hubungan antara elemen-elemen dan bangunan-bangunan secara keseluruhan sudah menjadi hubungan yang menyatu secara visual.

c. Ritme (rhythm), ritme di koridor jalan Pandanaran tidak terkesan monoton karena telah terbentuk komposisi yang serasi pada penekanan, interval atau jarak dan arah tertentu dari elemenelemen pembentuk ruang kota.

d. Skala (scale), perbandingan antara signage dan ruang sudah cukup seimbang.

e. Warna (colour), kombinasi warna cukup beraturan.

f. Serial vision, terdapat pemandangan antara lain focal point (Tugu Muda), punctuation (gapura kawasan yang termasuk ke dalam klasifikasi freestanding sign (pole sign), walaupun keberadaannya menurut responden arsitek tidak berpengaruh pada serial vision namun responden lain seperti masyarakat umum atau penghuni yang bukan berlatar belakang arsitek atau perancangan kota memandangnya sudah cukup baik), publicity (sangat terasa pada kawasan oleh-oleh Semarang dengan penumpukan signage sebagai commercial identity), trees in values center (keberadaan tanaman di kanan dan kiri jalan berfungsi sebagai penyejuk dari lingkungan), fluctuation (pergerakan terasa dengan adanya tinggi rendahnya bangunan-bangunan komersil yang ada di sepanjang koridor), deflection (pada belokan dimanfaatkan untuk meletakkan signage berupa roof sign searah dengan arah jalan sehingga menjadi eye catcher bagi yang pengendara), occupied territory (sangat terasa pada pedestrian di kawasan oleholeh Semarang) dan multiple view yang kesemuanya mendukung terciptanya serial vision yang ada di koridor Pandanaran.

\section{DAFTAR PUSTAKA}

Carr, Stephen, 1973, City, Sign and Light : a Policy Study, MIT Press, Cambridge.

Catanese, Antoni J. Snyder, James C. Susangko, 1986, Pengantar Perencanaan Kota, Penerbit Erlangga, Jakarta.

Echols, John M dan Shadily, Hasan, 1976. Kamus Inggris Indonesia, Penerbit PT. Gramedia, Jakarta.

Ishar, HK, 1992, Pedoman Umum Merancang Bangunan, Penerbit PT Gramedia, Jakarta.

Lynch, Kevin, 1969, The Image of the City, MIT Press, USA.

Lynch, Kevin, 1988, City Sense and City Design, The MIT Press, Cambridge.

Moughtin, Clift, 1992, Urban Design : Street and Square, Departement of Architecture and Planning University of Nottingham.

Moughtin, Clift ; Taner OC, Tiesdell, Steven, 1995, Urban Design Ornament and Decorated, Institute of Planning Studies, Departmen of Architecture and Planning University of Nottingham.

Rubenstein, Harvey M, 1992, Pedestrian Malls, Streetscape and Urban Spaces, John Wiley \& Sons, Canada.

Shirvani Hamid, 1985, The Urban Design Process, Van Nostrand Reinhold Company New York.

Sanoff, Henry, 1991, Visual Research Methods in Design, Van Nostrand Company Inc, New York. 